\title{
Pengaruh Penggunaan Model Project Based Learning Terhadap Keterampilan Kolaborasi Mahasiswa Pendidikan IPA
}

\author{
Sitti Saenab ${ }^{1}$, Sitti Rahma Yunus ${ }^{2}$, dan Husain ${ }^{3}$ \\ ${ }^{1,3}$ Prodi Pendidikan IPA FMIPA UNM \\ ${ }^{2}$ Jurusan Fisika FMIPA UNM \\ JL. Daeng Tata Raya Kampus FMIPA Parangtambung \\ ${ }^{1}$ Email: sitti.saenab@unm.ac.id
}

\begin{abstract}
Penelitian ini bertujuan untuk mengetahui pengaruh penggunaan model pembelajaran Project Based Learning terhadap keterampilan kolaborasi mahasiswa pendidikan IPA FMIPA UNM. Penelitian ini merupakan penelitian praeksperimen. Desain penelitian yang digunakan adalah One-Shot Case Study. Subyek penelitian adalah mahasiswa pendidikan IPA yang memprogramkan mata kuliah gerak dan perubahan. Instrumen penelitian yang digunakan untuk mengukur keterampilan kolaborasi mahasiswa adalah instrumen non tes yang terdiri dari rubrik dan angket. Analisis data dilakukan melalui statistik deskriptif dan statistik inferensial. Analisis data statistik deskriktif menunjukkan bahwa terjadi peningkatan keterampilan kolaborasi mahasiswa saat dibelajarkan menggunakan model Project Based Learning yaitu sebanyak 18 dari 29 mahasiswa berhasil mencapai skor di atas level 1. Sedangkan untuk uji inferensial menunjukkan bahwa terdapat pengaruh model pembelajaran Project Based Learning terhadap keterampilan kolaborasi mahasiswa
\end{abstract}

\section{Kata kunci: PjBL, Keterampilan Kolaborasi, Pendidikan IPA}

\begin{abstract}
This report aims to review the influence of the use of learning model learning project based on skill collaboration education students science education UNM. The research is praeksperimen research. A design study used is one- shot case study. Subjects research is a student science education that doing lecture motion and change. Research instruments used to measure skill collaboration students is the instrument non the tests which consisted of rubric and the survey. Analysis of data done through descriptive statistics and statistics inferential. Analysis deskriktif statistics show that increased skill collaboration students when dibelajarkan use the model project is based learning about 18 of 29 students able to reach the score over the level of 1 . While to test inferential shows that is the kind of classroom learning project based on skill collaboration
\end{abstract}

Key Words: PjBL, Skill Colobaration, Science Education

Partnership for $21^{\text {st }}$ century learning (P21) mengembangkan framework pembelajaran yang mengidentifikasi kompetensi dan keterampilan yang penting untuk kesuksesan 
dalam hidup dan karir. Framework ini didasarkan pada pernyataan bahwa abad 21 berisi tantangan yang menuntut peserta didik menguasai konten, memiliki keterampilan, kemahiran dalam berbahasa, serta kekuatan ekonomi dan politik yang mempengaruhi masyarakat (Grenhill. 2010:P21. 2015). Kompetensi dan keterampilan penting diabad 21 yang tertuang dalam framework abad 21 adalah critical thinking, communication, collaboration, dan creativity (4C). Keterampilan ini dapat membantu belajar dan beradaptasi dengan perubahan sepanjang waktu. Manusia membutuhkan pemahaman yang terintegrasi dari ide-ide besar ilmu dan kebiasaan pikiran seperti berpikir sistematis (P21. 2015).

Lembaga pendidik tenaga kependidikan bertujuan untuk mempersiapkan mahasiswa untuk memiliki kemampuan akademis dan professional. Jika saat ini mereka ingin bersaing di dunia global maka mereka harus mampu menjadi komunikator yang mahir, kreatif, berpikir kritis dan tentunya yang tak kalah pentingnya dalah mereka harus mampu bekerjasama, untuk itu perkuliahan seharusya diarahkan untuk membekali keterampilan tersebut. Keterampilan dalam bekerjasama merupakan salah satu kunci dalam mewujudkan proses pembelajaran yang efektif, dan ketermpialn ini dibutuhkan dalam dunia kerja. Kolaborasi merupakan jenis interaksi sosial dan proses belajar yang spesifik dimana anggota kelompok dapat secara aktif dan konstruktif dalam menyelesaikan permasalahan (Lee at al. 2015). Keterampilan kolaborasi mahasiswa dapat diketahui dengan cara memberikan berbagai tugas yang memasukkan unsur seperti proses menetapkan tujuan, membuat rencana, menghasilkan dan memilih strategi, mencoba solusi, merevisi rencana, dan sebagainya. Model pembelajaran yang dapat mewadahi aktivitas-aktivitas tersebut adalah model pembelajaran berbasis proyek.

Pembelajaran berbasis proyek merupakan salah satu model yang dapat diterapkan pada perkuliahan karena model ini memiliki potensi yang besar untuk menciptakan pengalaman bermakna bagi mahasiswa memasuki dunia kerja, pengalaman bermakna yang dimaksud antara lain dapat melatihkan kolaborasi yang baik. Edutopia (2006) melaporkan bahwa lingkungan kerja yang baru nantinya akan membutuhkan orang-orang yang memiliki kemampuan interpersonal dan manajemen proyek yang menuntut kerja tim. Hal ini menuntut peserta didik (mahasiswa) agar menjadi lulusan yang cakap berkomunikasi dengan baik dan cakap dalam berkolaborasi.

National Research Council Washington, DC (2013) menegaskan bahwa selain keterampilan komunikasi, siswa (mahasiswa) juga perlu diajarkan berkolaborasi dengan orang lain yang berbeda dalam latar budaya dan nilai yang dianutnya. Dalam menggali informasi dan membangun makna, siswa perlu didorong untuk bisa berkolaborasi dengan teman-teman di kelasnya. Dalam mengerjakan proyek, mahasiswa perlu dibelajarkan menghargai kekuatan dan talenta setiap orang serta mengambil peran dan menyesuaikan diri secara tepat. 
Model Project Based Learning (PjBL) pada penelitian ini dipilih dengan pertimbangan memiliki tahapan yang mampu mendorong mahasiswa berkolaborasi dengan anggota kelompok yang lain. Selain itu, sehubungan dengan landasan PjBL yang berorientasi pada pendekatan konstruktivis, penerapan model ini juga dapat memediasi mahasiswa membangun pengetahuan dari pengalamannya sendiri sehingga pembelajarannya lebih bermakna. Lebih jauh lagi diharapkan mahasiswa calon guru ini nantinya dapat menerapkan model-model pembelajaran bermakna kepada siswa ketika mereka sudah menjadi seorang guru sehingga peserta didik memiliki kompetensi (keterampilan) yang diharapkan dalam menghadapi tantangan abad XXI.

\section{METODE PENELITIAN}

Penelitian ini merupakan penelitian eksperimen dengan metode Pre-Experimental Design. Jenis penelitian ini menggunakan satu kelompok subyek yang diberikan perlakuan dan tidak memiliki kelas kontrol. Desain penelitian yang digunakan adalah One- Shot Case Study. Pada desain ini, diberikan perlakuan terhadap mahasiswa kemudian dilakukan observasi tentang keterampilan kolaborasi dari aktivitas pembelajaran mahasiswa. Desain penelitian ini dapat digambarkan sebagai berikut:

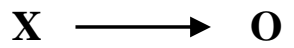

Gambar 1. Desain Eksperimen One-Shot Case Study

(Sumber: Arikunto, 2013).

Keterangan:

X : Model pembelajaran Project Based Learning (PjBL).

$\mathrm{O}$ : Skor perolehan keterampilan kolaborasi mahasiswa setelah diberi perlakuan.

Dalam penelitian ini terdapat dua macam variabel, yakni:

a) Variabel bebas : Model pembelajaran Project Based Learning (PjBL)

b) Variabel terikat : Keterampilan kolaborasi

Populasi dalam penelitian ini adalah seluruh mahasiswa prodi pendidikan IPA FMIPA UNM pada semester ganjil tahun ajaran 2016/2017, sedangkan sampel pada penelitian ini adalah mahasiswa pendidikan IPA UNM kelas reguler semester 3 tahun ajaran 2016/2017.

Penelitian ini dilaksanakan dengan dua tahap yaitu tahap persiapan dan tahap pelaksanaan.

1. Tahap Persiapan

Kegiatan yang dilakukan pada tahap persiapan sebagai berikut:

a) Melakukan observasi awal pada mahasiswa pendidikan IPA UNM tahun ajaran 2016/2017 untuk mendapatkan informasi yang dibutuhkan dalam pembuatan rencana penelitian. 
b) Validasi instrumen penelitian yaitu silabus, rencana pelaksanaan pembelajaran,) rubrik keterampilan komunikasi dan kolaborasi dan self-assessment (angket).

2. Tahap Pelaksanaan

Penelitian ini menggunakan satu kelompok eksperimen sebagai subyek penelitian yaitu mahasiswa pendidikan IPA UNM kelas reguler semester 3 tahun ajaran 2016/2017. Waktu pelaksanaan terdiri dari dua tahap dimana tahap pertama dilakukan sebanyak 2 kali pertemuan untuk memperoleh gambaran awal tentang keterampilan komunikasi dan kolaborasi mahasiswa sebelum diberi perlakuan menggunakan model Project Based Learning (PjBL). Tahap kedua dilakukan selama 3 kali pertemuan pada mata kuliah gerak dan perubahan untuk memperoleh gambaran keterampilan kolaborasi mahasiswa saat dibelajarkan menggunakan model Project Based Learning (PjBL). Rincian tahapan pelaksanaan penelitian diuraikan sebagai berikut:

a) Melakukan observasi aktivitas mahasiswa saat berdiskusi dan presentasi dengan panduan rubrik untuk memperoleh gambaran awal keterampilan kolaborasi mahasiswa sebelum dibelajarkan menggunakan model pembelajaran Project Based Learning (PjBL).

b) Melakukan observasi aktivitas mahasiswa saat dibelajarkan menggunakan model pembelajaran Project Based Learning (PjBL). Penilaian keterampilan kolaborasi diperoleh dari aktivitas mahasiswa sesuai tahapan model project based learning yang dirincikan pada Tabel 3.1 berikut:

Tabel 1. Tahapan model Project Based Learning (PjBL)

\begin{tabular}{|c|c|c|}
\hline Fase PjBL & Aktivitas Mahasiswa & Penilaian \\
\hline $\begin{array}{l}\text { Introduction } \\
\text { Pengenalan rencana } \\
\text { pelaksanaan pembelajaran } \\
\text { berbasis proyek }\end{array}$ & $\begin{array}{l}\text { a) Membentuk kelompok belajar } \\
\text { atau kelompok kerja proyek } \\
\text { b) Mendeskripsikan konsep materi } \\
\text { mengenai prinsip-prinsip gerak } \\
\text { pada makhluk hidup } \\
\text { c) Mendeskripsikan konsep materi } \\
\text { mengenai gerak pada hewan } \\
\text { d) Mendeskripsikan konsep materi } \\
\text { mengenai gerak pada tumbuhan }\end{array}$ & Observasi \\
\hline $\begin{array}{l}\text { Essential Question } \\
\text { Pertanyaan mendasar }\end{array}$ & $\begin{array}{l}\text { Menjawab pertanyaan mendasar } \\
\text { yang mengantarkan mahasiswa } \\
\text { pada ide awal proyek }\end{array}$ & Observasi \\
\hline $\begin{array}{l}\text { Research and Write } \\
\text { Studi literatur dan menulis } \\
\text { rancangan proyek }\end{array}$ & $\begin{array}{l}\text { a) Membaca berbagai sumber } \\
\text { literatur untuk mengumpulkan } \\
\text { informasi } \\
\text { b) Melakukan pengamatan dan } \\
\text { memulai penelitian untuk } \\
\text { membuat rancangan proyek }\end{array}$ & Rubrik kolaborasi \\
\hline
\end{tabular}

BIOLOGI SEL (VOL 8 NO 1 EDISI JAN-JUN 2019 ISSN 2252-858X/E-ISSN 2541-1225) PAGE 32 


\begin{tabular}{|l|l|l|}
\hline & c) $\begin{array}{l}\text { Membuat ringkasan hasil } \\
\text { penelitian (studi literatur) yang } \\
\text { telah dilakukan }\end{array}$ & \\
& d) $\begin{array}{l}\text { Menyusun (menulis) rancangan } \\
\text { proyek } \\
\text { Mendiskusikan rancangan } \\
\text { proyek yang telah dibuat } \\
\text { Product Creation }\end{array}$ & \\
Melakukan Proyek & f) $\begin{array}{l}\text { Memprentasikan rancangan } \\
\text { proyek yang telah disepakati }\end{array}$ & \\
\hline $\begin{array}{l}\text { Presentation } \\
\text { Presentasi }\end{array}$ & Melakukan proyek & Rubrik kolaborasi \\
\hline Evaluation and Reflection & Mengisi self-assessment & Selfassessment (Angket \\
Evaluasi dan Refleksi & & Keterampilan Kolaborasi) \\
\hline
\end{tabular}

Teknik pengumpulan data dilakukan dengan cara pemberian self assessment (angket penilaian keterampilan kolaborasi) yang diisi oleh mahasiswa, dan rubrik yang diisi oleh observer. Rubrik didefinisikan sebagai scoring scale atau penskoran dengan skala tertentu yang digunakan untuk menilai hasil aktivitas mahasiswa berdasarkan beberapa standar kriteria. Rubrik mendeskripsikan tentang kualitas indikator dari level tertinggi hingga level terendah. Terpadat empat level skala pada rubrik yakni patut dicontoh (4); Ahli (3); Pemula (2); dan Percobaan/orang baru (1); (Greenstein, 2012). Rubrik penilaian pada penelitian ini meliputi rubrik keterampilan kolaborasi mahasiswa yang diukur sebelum dan pada saat aktivitas belajar mahasiswa dengan menggunakan model Project Based Learning (PjBL).

\section{Self-assessment (Penilaian diri sendiri)}

Penilaian diri sendiri diberikan kepada masing - masing mahasiswa dalam bentuk angket, diisi di akhir pembelajaran atau setelah melakukan aktivitas pembelajaran. Angket pada penelitian ini terdiri dari 38 pernyataan untuk mengetahui kolaborasi mahasiswa.

Analisis data dilakukan melalui statistik deskriptif dan statistik inferensial. Semua data dihimpun dan diintegrasikan kemudian dianalisis secara menyeluruh untuk penyusunan kesimpulan penelitian mengenai pengaruh model pembelajaran Project Based Learning (PjBL) terhadap kolaborasi mahasiswa pendidikan IPA UNM pada materi gerak dan perubahan. Penjabaran pengolahan data adalah sebagai berikut:

\section{Analisis angket (Self-assessment)}

Tahapan analisis angket keterampilan kolaborasi adalah sebagai berikut:

1) Mentabulasi jawaban angket yang diisi oleh mahasiswa

2) Menghitung persentase jawaban mahasiswa untuk setiap pernyataan pada angket dengan rumus: 


$$
\% \mathrm{X}=\frac{\text { Jumlah iawahan siswa }}{\text { Skor Maksimum }} \times 100 \%
$$

3) Melakukan interpretasi terhadap jawaban angket berdasarkan kriteria pengkategorian sebagai berikut:

Tabel 2. Kategori Skor Angket Keterampilan Kolaborasi Mahasiswa

\begin{tabular}{|c|c|}
\hline Rentang Persentase (\%) & Kategori \\
\hline $0-20$ & Sangat Lemah \\
\hline $21-40$ & Lemah \\
\hline $41-60$ & Cukup \\
\hline $61-80$ & Kuat \\
\hline $81-100$ & Sangat Kuat \\
\hline
\end{tabular}

(Sumber: Riduwan 2014)

\section{Analisis rubrik keterampilan kolaborasi}

Rubrik yang digunakan terdiri dari empat skala scoring yakni patut dicontoh (4); ahli (3); pemula (2); dan percobaan/Orang baru (1); total skor dikategorikan menjadi 4 kategori yaitu tingkat dasar, tingkat sedang, tingkat terlatih dan tingkat tertinggi dengan pengkategorian dapat dirujuk pada Tabel 3.3.

Tabel 3. Kategori Skor Rubrik Keterampilan Kolaborasi Mahasiswa

\begin{tabular}{|l|l|}
\hline \multicolumn{1}{|c|}{ Skor } & \multicolumn{1}{c|}{ Kategori } \\
\hline $1.0-2.7$ & Level 1: Tingkat Dasar \\
\hline $2.8-3.1$ & Level 2: Tingkat Sedang \\
\hline $3.2-3.5$ & Level 3: Tingkat Terlatih \\
\hline $3.6-4.0$ & Level 4: Tingkat Tinggi \\
\hline
\end{tabular}

(Sumber: Greenstein, 2012)

Teknik analisis statistik inferensial digunakan untuk menguji hipotesis penelitian. Pengujian hipotesis menggunakan uji t yang sebelumnya telah dilakukan uji normalitas. Perolehan data dianalisis dengan menggunakan program Statistical Package for Social Sciense (SPSS) versi 20.0.

\section{HASIL DAN PEMBAHASAN}

\section{Deskripsi Data Skor Rubrik Keterampilan Kolaborasi}

Berdasarkan hasil pengamatan peneliti sebelum mahasiswa dibelajarkan menggunakan model Project Based Learning (Pra-PjBL) dan pada saat mahasiswa dibelajarkan menggunakan model Project Based Learning (Post-PjBL), maka diperoleh rata - rata skor keterampilan kolaborasi yang diuraikan pada Tabel 4 
Tabel 4. Rerata Skor Rubrik Keterampilan Kolaborasi Mahasiswa pada Pra-PjBL dan Post-PjBL

\begin{tabular}{|l|c|c|}
\hline $\begin{array}{l}\text { Skor Rubrik } \\
\text { Keterampilan } \\
\text { Kolaborasi }\end{array}$ & Pra-PjBL & Post-PjBL \\
\hline Skor Maksimum & 1.50 & 3.63 \\
\hline Skor Minimum & 0.25 & 1.81 \\
\hline Rata - rata & 1.09 & 2.96 \\
\hline Kategori & Level 1 & Level 2 \\
\hline
\end{tabular}

Rata - rata skor rubrik keterampilan kolaborasi pada Tabel 4.3 menunjukkan peningkatan keterampilan kolaborasi mahasiswa saat dibelajarkan dengan menggunakan model Project Based Learning (Post-PjBL) yaitu sebesar 1.87. Distribusi skor rubrik keterampilan kolaborasi mahasiswa pada Pra-PjBL dan Post-PjBL dapat diuraikan dalam grafik berikut:

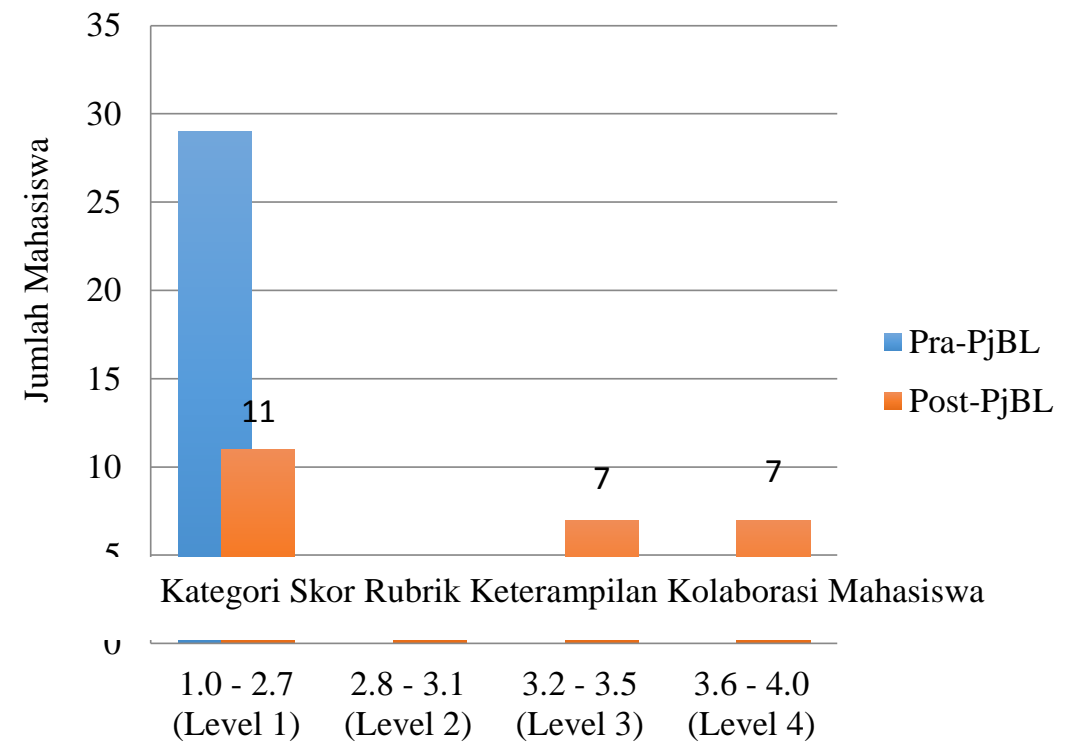

Gambar 2. Grafik Distribusi Skor Rubrik Keterampilan Kolaborasi Mahasiswa

Distribusi skor keterampilan kolaborasi pada Gambar 2 menunjukkan peningkatan keterampilan kolaborasi mahasiswa saat dibelajarkan menggunakan model Project Based Learning (PjBL) yaitu sebanyak 18 dari 29 mahasiswa berhasil mencapai skor di atas level 1.

\section{Deskripsi Data Skor Angket Keterampilan Kolaborasi Mahasiswa}

Perolehan persentase rata-rata skor angket per aspek keterampilan kolaborasi mahasiswa dapat diamati pada Tabel 5 
Tabel 5. Persentase rata - rata skor angket per aspek keterampilan kolaborasi

\begin{tabular}{|c|l|c|c|}
\hline No. & \multicolumn{1}{|c|}{ Aspek Kolaborasi } & $\begin{array}{c}\text { Persentase } \\
(\boldsymbol{\%})\end{array}$ & Kategori \\
\hline 1 & Bekerja secara produktif & 68.6 & Kuat \\
\hline 2 & Menunjukkan sikap hormat -menghormati & 69.3 & Kuat \\
\hline 3 & Saling Bersepakat & 74.7 & Kuat \\
\hline 4 & Berbagi tanggung jawab dan berkontribusi & 61.5 & Kuat \\
\hline \multicolumn{2}{r|}{ Total } & $\mathbf{6 8 . 5}$ & Kuat \\
\hline
\end{tabular}

Persentase skor keterampilan kolaborasi tertinggi berdasarkan Tabel 4.4 diperoleh pada aspek "Saling Bersepakat" sementara persentase skor terendah ditunjukkan oleh aspek "Berbagi Tanggung Jawab dan Berkontribusi". Distribusi persentase skor angket keterampilan kolaborasi mahasiswa dapat diuraikan dalam bentuk grafik seperti berikut:

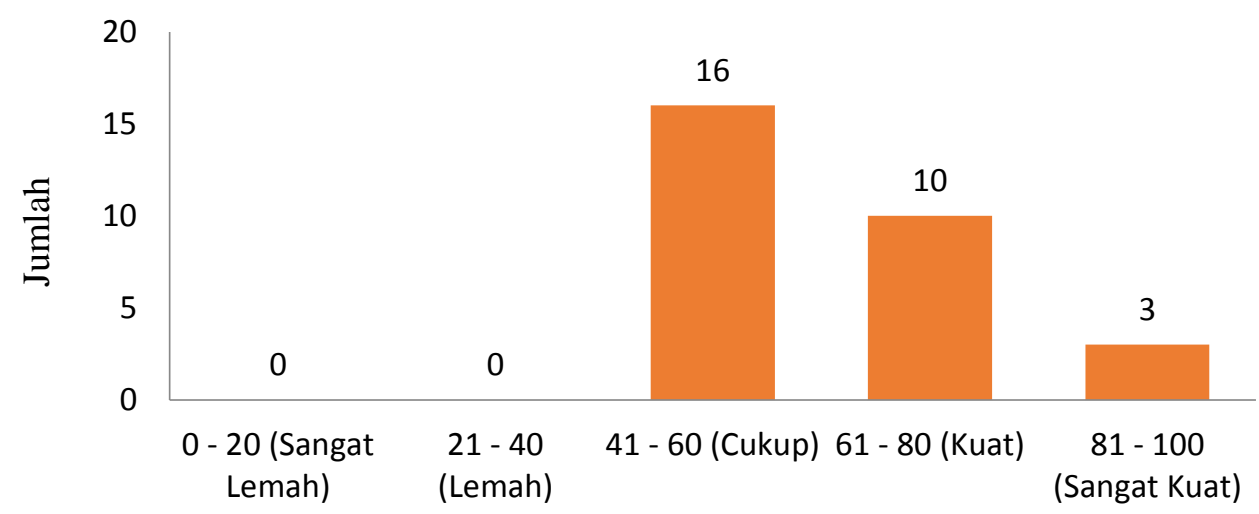

Kategori Skor Angket Keterampilan Kolaborasi Mahasiswa

Gambar 3. Distribusi Persentase Skor Angket Keterampilan Kolaborasi Mahasiswa

Gambar 3 menunjukkan bahwa terjadi peningkatan keterampilan kolaborasi mahasiswa saat dibelajarkan menggunakan model Project Based Learning (PjBL), dimana seluruh mahasiswa mencapai skor di atas kategori lemah.

\section{Hasil Analisis Inferensial}

\section{Uji Normalitas}

Uji normalitas yang digunakan adalah uji Kolmogorov-Smirnov menggunakan Statistical Package For Social Sciense (SPSS) versi 20.0 dengan taraf signifikansi $\alpha=$ 0.05 . Hasil uji normalitas dapat dilihat pada tabel berikut: 
Tabel 6. Hasil Uji Normalitas Pra-PjBL dan Post-PjBL Keterampilan Kolaborasi

\begin{tabular}{|l|l|c|c|l|}
\hline $\begin{array}{c}\text { Jenis } \\
\text { Keterampilan }\end{array}$ & \multicolumn{1}{|c|}{ Data } & Sampel (N) & Signifikansi & \multicolumn{1}{c|}{ Kesimpulan } \\
\hline Kolaborasi & Pra-PjBL & 29 & 0.071 & Data terdistribusi normal \\
\cline { 2 - 5 } & Post-PjBL & 29 & 0.345 & Data terdistribusi normal \\
\hline
\end{tabular}

Pengujian data dengan menggunakan uji Kolmogorov-Sminornov menunjukkan data terdistribusi normal apabila nilai signifikansi $>\alpha$ dan sebaliknya jika nilai signifikansi $\leq \alpha$, maka sampel tidak terdistribusi normal. Berdasarkan Tabel 4.6, semua data terdistribusi normal.

\section{Pengujian hipotesis}

Menurut Purwanto (2011), pengujian hipotesis dapat ditentukan dengan kriteria apabila $\mathrm{p}$-value $>\alpha(0,05)$ maka $\mathrm{H}_{0}$ diterima, $\mathrm{H}_{1}$ ditolak. Jika $\mathrm{p}$-value $<\alpha(0,05)$ maka $\mathrm{H}_{0}$ ditolak, $\mathrm{H}_{1}$ diterima. Hasil uji hipotesis keterampilan komunikasi dan kolaborasi mahasiswa dapat diamati pada Tabel 7 berikut:

Tabel 7. Hasil Uji Hipotesis Keterampilan Kolaborasi

\begin{tabular}{|c|c|c|c|c|}
\hline Data & $\begin{array}{c}\text { Jumlah } \\
\text { Sampel (N) }\end{array}$ & $\mathbf{t}_{\text {hitung }}(\mathbf{t})$ & $\begin{array}{c}\text { Derajat } \\
\text { Kebebasan } \\
\text { (Df) }\end{array}$ & $\begin{array}{c}\text { Nilai } \\
\text { Signifikansi (p- } \\
\text { value) }\end{array}$ \\
\hline $\begin{array}{c}\text { Keterampilan } \\
\text { Kolaborasi } \\
\text { (Pra_Project- } \\
\text { Post_Project })\end{array}$ & 29 & 28.180 & 28 & 0.000 \\
\hline
\end{tabular}

Tabel 7 menunjukkan nilai thitung Keterampilan kolaborasi adalah 28.180, sedangkan nilai $t_{\text {tabel }}$ dengan derajat kebebasan $(\mathrm{Df})=28$ pada taraf signifikansi dua pihak adalah $t_{\text {tabel }}=2.048$. Oleh karena $t_{\text {hitung }}>t_{\text {tabel }}(p$-value $<0.05)$ dan nilai signifikansi yang diperoleh yaitu Sig. (2-tailed) $0.000<\alpha(0,05)$ maka $\mathrm{H}_{0}$ ditolak dan $\mathrm{H}_{1}$ diterima. Ini berarti bahwa terdapat pengaruh model pembelajaran Project Based Learning (PjBL) terhadap keterampilan kolaborasi mahasiswa.

Hasil analisis deskriptif rubrik keterampilan kolaborasi menunjukkan peningkatan saat mahasiswa dibelajarkan dengan model pembelajaran Project Based Learning (PjBL). Berdasarkan perolehan rata - rata skor rubrik keterampilan kolaborasi, dapat diketahui bahwa peningkatan yang terjadi cukup signifikan dengan kategori rata - rata keterampilan kolaborasi mahasiswa yang berada pada level 2. Jika ditinjau dari distribusi perolehan skor rubrik keterampilan kolaborasi, beberapa mahasiswa berhasil mencapai skor di atas level 1. Hal ini juga didukung oleh distribusi persentase skor angket keterampilan kolaborasi yang menunjukkan beberapa mahasiswa berada pada kategori kuat bahkan ada pula mahasiswa yang mencapai kategori sangat kuat. Sehingga dapat dikatakan bahwa model Project Based Learning (PjBL) memberikan pengaruh terhadap keterampilan kolaborasi mahasiswa. 
Berdasarkan perolehan persentase rata - rata skor angket untuk setiap aspek keterampilan kolaborasi mahasiswa, menunjukkan range dengan persentase skor di atas 60 dan dikategorikan 'kuat'. Aspek tertinggi pada keterampilan kolaborasi baik dari rata - rata perolehan skor angket maupun rubrik adalah aspek 'saling bersepakat'. Ini berarti bahwa hampir seluruh mahasiswa fleksibel dalam bekerja sama dan mampu bersepakat untuk mencapai tujuan dari proyek yang dikerjakan.

Menurut Roshelle dan Teasley dalam Huang (2002), keterampilan kolaborasi yang melibatkan siswa pada proses dealing atau kesepakatan untuk menetapkan suatu keputusan sangat menentukan dari keberhasilan proyek. Hal ini diperkuat oleh hasil penelitian dari Universitas Indianapolis, Chan Lin dalam Notari (2013) yang menemukan bahwa Project Based Learning (PjBL) menunjukkan kelebihan dalam mengembangkan keterampilan kolaborasi siswa. Karena melalui aktivitas kompleks dari model tersebut, siswa mampu saling bersepakat dan saling menghargai terhadap pendapat yang berbeda - beda untuk menemukan solusi dan mencapai tujuan utama dari pelaksanaan proyek.

Distribusi skor rubrik keterampilan kolaborasi memberikan pula informasi bahwa indeks pencapaian skor keterampilan kolaborasi mahasiswa saat diberi perlakuan model pembelajaran Project Based Learning (PjBL) sebanding dengan peningkatakan skor keterampilan komunikasi. Skor tertinggi untuk keterampilan komunikasi dan kolaborasi mahasiswa mencapai level 4. Hal ini diperkuat oleh persentase skor angket keterampilan komunikasi dan kolaborasi mahasiswa yang tertinggi mencapai kategori 'Sangat Kuat'. Menurut Priansa (2015), karakteristik dari model Project Based Learning (PjBL) adalah mengutamakan aktivitas peserta didik dalam kerja tim untuk menghimpun konsep dan pengetahuannya, sehingga diantara keterampilan yang dibutuhkan siswa dalam mengerjakan proyek adalah keterampilan kolaborasi dan komunikasi. Sejalan dengan hal tersebut, Huang (2002) menguraikan bahwa banyak peneliti sebelumnya yang telah mengidentifikasi keterampilan kolaborasi dan komunikasi sebagai faktor pendukung dalam kesuksesan kerja proyek. Oleh karena itu, berdasarkan hasil penelitian Kafai dalam Huang (2002), menemukan bahwa peningkatan keterampilan kolaborasi sebanding dengan peningkatan keterampilan komunikasi karena melalui keterlibatan siswa dalam kerja tim, siswa memiliki kesempatan untuk mengekspresikan idenya, berbagi gagasan dan pengetahuan, serta saling membantu antaranggota tim.

Hasil temuan empiris dari penelitian ini membuktikan temuan Kafai, dimana peningkatan keterampilan kolaborasi mahasiswa berbanding lurus dengan peningkatan keterampilan komunikasinya. Hal tersebut dapat dipengaruhi karena tahapan Project Based Learning (PjBL) sangat ketat melibatkan kerja sama masing - masing anggota tim mulai dari tahap persiapan proyek hingga tahap presentasi. Sehingga masing - masing anggota tim bertanggungjawab dan aktif terlibat dalam pengerjaan proyek yang mendukung proses komunikasi anggota tim dalam melaporkan masing - masing tanggungjawabnya dan mengkomunikasikan temuan dari proyeknya. Berdasarkan hasil 
analisis inferensial menunjukkan bahwa nilai signifikansi keterampilan komunikasi dan kolaborasi yang diperoleh melalui uji statistik parametrik, Paired Sample t-test diperoleh nilai $t_{\text {hitung }}>\mathrm{t}_{\text {tabel }}\left(\mathrm{p}\right.$-value $<0.05$ ), dimana nilai $t_{\text {hitung }}$ Keterampilan komunikasi= 17.741; $t_{\text {hitung }}$ Keterampilan kolaborasi $=28.180$, sedangkan nilai $t_{\text {tabel }}$ dengan derajat kebebasan (Df) $=28$ pada taraf signifikansi dua pihak adalah $\mathrm{t}_{\text {tabel }}=2.048$ dan nilai signifikansi yang diperoleh yaitu Sig. (2-tailed) $0.000<\alpha(0,05)$. Dari perolehan nilai signifikansi tersebut, dapat diinterpretasikan bahwa $\mathrm{H}_{0}$ ditolak dan $\mathrm{H}_{1}$ diterima. Dengan demikian, hal ini mendukung hasil analisis deskriptif yang menyatakan bahwa model pembelajaran Project-Based Learning berpengaruh terhadap keterampilan komunikasi dan kolaborasi mahasiswa.

\section{KESIMPULAN}

Dari hasil penelitian dapat disimpulkan bahwa penggunaan model pembelajaran Project Based Learning berpengaruh terhadap keterampilan kolaborasi mahasiswa Pendidikan IPA FMIPA UNM.

\section{DAFTAR PUSTAKA}

Badan Standar Nasional Pendidikan. (2010). Laporan BSNP Tahun 2010. Jakarta: Badan Standar Nasional Pendidikan.

Bell, S. (2010). Project Based Learning for The $21^{\text {st }}$ Century: Skills for The Future. The Clearing House. Routledge Tailor \& Francis Group. 83: 39-43.

Bellanca, J. 2012. Proyek Pembelajaran yang Diperkaya: Jalur Praktis Menuju Keterampilan Abad ke-21. Jakarta: Indeks.

Bellanca, J., \& Terry, S. (2011). Classroom Without Borders: Using Internet Project to Teach Communication and Collaboration. New York: Teachers College, Collumbia University.

Bender, W. N. (2012). Project Based Learning: Differentiating Instruction for The $21^{\text {st }}$ Century. United State of America: Corwin

Cameron, S., \& Carolyn C. (2014). Project-Based Learning Task for Common Core State Standards, Grade 6-8. United State of America: Mark Twain Media, Inc.

Departemen Pendidikan Nasional (Depdiknas). (2003). Standar Kompetensi Bahan Kajian: Pelayanan Profesioanal Kurikulum Berbasis Kompetensi. Jakarta: Puskur Balitbang.

Greenstein, L. (2012). Assessing $21^{\text {st }}$ Century Skill: A Guide to Evaluating Mastery and Authentic Learning. United States of America: Corwin A Sage Company.

Greenhill, Valerie. (2010). 21st Century Knowledge and Skills in Educator Preparation. American Association of Colleges for Teacher Education; Partnership for 21st Century Skills 
Huang, D., Seth, L., Cheri, H., Debora, L.T., Nora, O., \& Gwendelyn, R. (2010). Preparing Students for The $21^{\text {st }}$ Century: Exploring The Effect of Afterschool Participation on Students' Collaboration Skills, Oral Communication Skills, and Self-Efficacy. Cress Report (CR) of The National Center for Research on Evaluation, Standards, and Student Testing. University of California: Los Angeles, CR 777.

Lee, Huh, Reigeluth. (2015). Collaboration, intragroup conflict, and social skills in project-based learning. Instructional science. Volume 43, Issue 5, pp 561-590. Springer.

Musa, F., Norlaila, M., Rozmel A.B., \& Maryam M. A. (2011). Project Based Learning (PjBL): Inculcating Soft Skills in $21^{\text {st }}$ Century Workplace. Procedia-Social and Behavioral Sciences, Elsevier, 59 (2012) 565 - 573.

National Research Council of The National Academies. (2013). Education for Life and Work: Developing Transferable Knowledge and Skills for 21st Century. Washington, DC: The National Academies Press.

National Science Teachers Association (NSTA). (2011). The NSTA Reader's Guide to A Framework for K-12 Science Education. Virginia: NSTA Press.

Notari, M., Baumgartnert, A., Herzogt, W. (2013). Social Skills as Predictors of Communication, Performance and Quality of Collaboration in Project Based Learning. Journal of Computer Assisted Learning, 30. 132 - 147

Partnership for 21st Century Skills. (2002) Learning for The 21 st Century: A Report and Mile Guide to 21st Century Skills. United State of America: U.S. Department of Education.

Partnership for 21st Century Skills. (2015) P21 Framework Defenitions. United State of America: U.S. Department of Education.

Pearlman, B. (2006). Project Based Learning Teaches Kids the Collaborative and Critical Thinking Abilities They Will Need to Compete. A New Skills for A New Century, 51 - 53. June, 2006.

Patton, A., \& Jeff, R. (2012). Work that Matters: The Teacher's Guide to Project Based Learning. United Kingdom: Paul Hamlyn Foundation.

Priansa, D.J. (2015). Manajemen Peserta Didik dan Model Pembelejaran. Bandung: Alfabeta.

Rais. (2010). Project Based Learning: Inovasi Pembelajaran yang Berorientasi Soft Skill. Makalah disajikan dalam Seminar Nasional Pendidikan Teknologi dan Kejuruan Fakultas Teknik Universitas Negeri Surabaya, Surabaya. 11 Desember.

Riduwan. (2014). Dasar - dasar Statistika. Bandung: Alfabeta.

Roekel, D.V. (2011). Preparing 21 ${ }^{\text {st }}$ Century Students for a Global Society: An Educator's Guide to The "Four Cs". Washington, DC: NEA (National Education Association). 
Sukmadinata, N.S. (2011). Metode Penelitian Pendidikan. Rosdakarya. Jakarta.

Shadaika, M. (2013). Pengaruh Model Project Based Learning Berbasis Potensi Makroalga Daerah Pesisir Terhadap Kemampuan Berpikir Kritis Siswa pad Materi Ekosistem di SMA Negeri 1 Tanjungsari Gunungkidul DIY. Makalah disajikan dalam Seminar Nasional Konservasi dan Pemanfaatan Sumber Daya Alam, Surakarta. 13 Januari 2015.

Tim Pengajar Deakin. (2013). The Series of Teaching Resources. Melbourne: DLF 